Paper published as follows: Polido, A., João, E. and Ramos, T. (2016), Strategic Environmental Assessment practices in European small islands: Insights from Azores and Orkney islands. Environmental Impact Assessment Review ,Volume 57, February 2016, Pages 18-30.

\title{
Strategic Environmental Assessment Practices in European Small Islands: Insights from Azores and Orkney Islands
}

\section{Abstract}

The literature concerning Strategic Environmental Assessment (SEA) often refers to the importance of context-specific approaches. However, there is a lack of systematised and consistent studies that enhance tailor-made SEA practices and procedures. Small islands are bounded units of study which may help explore SEA theory and practice in special territories. Small islands present particular features and unique values, such as, small size and population, geographic isolation, limited resources and vulnerable ecosystems. Hence, the main goal of this research was to profile SEA practices and procedures in European small islands and provide a background for future research aiming to improve context-specific SEA applications. To achieve this goal, an exploratory case study was developed using Azores (Portugal) and Orkney (Scotland) archipelagos. An analysis of the corresponding mainland was also carried out to contextualise both case studies. The data collection was achieved through a qualitative content analysis of 43 Environmental Reports. The research found that there is not an SEA context-specific approach used within these European small islands, including guidelines, assessment topics, assessment techniques, follow-up and stakeholders engagement. The debate concerning specific approaches to small islands must be re-focused on the enhancement of SEA capacity-building amongst different stakeholders (including decision-makers), on the development and implementation of collaborative approaches, and on the exchange of knowledge and experiences between small islands networks.

Keywords: Strategic Environmental Assessment; sustainability; context; small islands; Azores; Portugal; Orkney; Scotland.

\section{Introduction}

Several authors stress that Strategic Environmental Assessment (SEA) should be context-specific (e.g., Fischer and Gazzola, 2006; Gunn and Noble, 2009; Hildén et al., 2004). However, this argument has led to SEA approaches which can be vague and confusing (Noble et al., 2012). To counteract this, SEA has had to evolve and there are new approaches emerging in its practice. This includes: the integration of ecosystems services in SEA (Baker et al., 2013); resilience thinking linked with SEA (Slootweg and Jones, 2011); and more recently, evolutionary resilience (Bond et al., 2015). These approaches require a context-specific consideration and may provide a valuable framework for SEA practices in a particular type of decision-making process. Hence, territories with specific features and characteristics have needs that must be reflected in the SEA (Gunn and Noble, 2009; Polido et al., 2014).

Small Islands are vulnerable and unique territories (Bass and Dalal-Clayton, 1995; Douglas, 2006). Due to characteristics such as relatively small size, geographic isolation, a narrow economic base, limited resources, ecosystems vulnerable to other external ecological influences, and relatively small populations with a narrow skills base (McIntyre, 2005; Ramjeawon and Beedassy, 2004), small islands become the target of international attention (UNCED 1992; United Nations 1994). In particular, the international community understands the urgent need for sustainability-led approaches in the islands' decision-making system (Bass and Dalal-Clayton, 1995; Deschenes and 
Paper published as follows: Polido, A., João, E. and Ramos, T. (2016), Strategic Environmental Assessment practices in European small islands: Insights from Azores and Orkney islands. Environmental Impact Assessment Review ,Volume 57, February 2016, Pages 18-30.

Chertow, 2004). Several authors still discuss how this can be done, since sustainability may be paradoxical in these territories and demand different approaches (Bass and Dalal-Clayton, 1995; Kerr, 2005; Zubair et al., 2011). As shown by Polido et al. (2014), SEA has the potential to fill this gap since it links the three key arguments found to enhance sustainability in small islands: (a) change in decision-making paradigm, (b) good governance and community empowerment, and (c) resilience.

Additionally, small islands are living laboratories for the planet, since they are a closed and bounded system, and thus manageable units of study (Nagarajan, 2006) which can influence future discussion on SEA and sustainability. They therefore deserve increased attention from the academic community as well as from the international institutions (Bass and Dalal-Clayton, 1995; Crossley and Sprague, 2014). Even though literature and studies mainly focus on Small Islands Developing States (SIDS), as reviewed by Polido et al. (2014), Adrianto and Matsuda (2002) argue that small islands in general have common economic and environmental characteristics. Newitt (1992), also states that small islands share the same characteristics to different extents, stressing that there are three different categories of islands: (i) independent islands States, such as SIDS, (ii) islands that are an autonomous region of a mainland state, as is the case of the Azores, and (iii) islands under the rule of the mainland state, such as the Scottish islands (e.g., Orkney).

As noted by Montaño et al. (2014) the number of studies assessing SEA systems is increasing, allowing inferences about the importance of the context in SEA. The common items between the different approaches are (i) legal basis for SEA application and guidance tools; (ii) existing process and procedural framework (including stages of the SEA (e.g., screening, scoping, environmental assessment, public participation, follow-up) and assessment methodologies and components (assessment techniques and issues)); (iii) SEA review and influence to the decision-making (Chaker et al., 2006; Rachid and El Fadel, 2013; Therivel, 1993; Zhou and Sheate, 2009). These items reflect issues required by good SEA practices and depend on the type of analysis planned (Zhou and Sheate, 2009). Even though there is literature reflecting overall good practice on SEA (e.g., Abaza et al., 2004; Fischer, 2002), methodological approaches and assessment techniques (e.g., Fischer, 2007; Noble et al., 2012; OECD , 2006; Therivel, 2004; UNEP , 2009), there is also literature providing focus on specific components of the assessment, for instance, on follow-up (e.g., Fischer, 2007; MorrisonSaunders et al., 2014; Nilsson et al., 2009; Partidário and Fischer, 2004), and stakeholder engagement (e.g., Doren et al., 2013; Gauthier et al., 2011; IAIA , 2002; Ren and Shang, 2005).

Despite the above research exploring the importance of context on SEA approaches or discussing sustainability related approaches, there is a dearth of research on initiatives that offer a coherent integrated analysis of SEA and sustainability assessment in small islands (Polido et al., 2014). To help fill this research gap, the aim of this analysis was to evaluate the state of integration of the SEA practices and procedures in small islands and understand what might be improved in the SEA of these islands.

To achieve the research aim, the Azores and Orkney archipelagos were used as an exploratory case study, following the research approaches by Yin (2009). A comparative assessment with the Portuguese and Scottish mainland was carried out in order to understand the SEA national context of the archipelagos. The data collection was achieved through a qualitative content analysis, following the research approaches by Bardin (1977), Krippendorff (2003), and Mayring (2000), of 43 
Paper published as follows: Polido, A., João, E. and Ramos, T. (2016), Strategic Environmental Assessment practices in European small islands: Insights from Azores and Orkney islands. Environmental Impact Assessment Review ,Volume 57, February 2016, Pages 18-30.

Environmental Reports (ER) (viz. 7 from Azores, 14 from the Portuguese mainland, 5 from Orkney and 17 from the Scottish mainland). The qualitative content analysis criteria were developed taking into account the literature on comparative assessment of SEA systems, their practices and procedures.

The paper starts by characterising the Portuguese and Scottish SEA system, to establish the background of the research (Section 2). It then explains and justifies the research design, including the choice of the case studies (Azores and Orkney) and the development of the qualitative content analysis criteria for the data collection and analysis (Section 3). Following this, the paper presents the relevant results and findings from the empirical studies (Section 4), and a cross-case analysis adding a comprehensive integrative examination of both cases (Section 5). The final section concludes by showing possible ways to develop research and practice of SEA in small islands.

\section{The Portuguese and Scottish SEA System}

The Portuguese and Scottish SEA systems both need to comply with the EU SEA Directive ${ }^{1}$. However, contrary to what would be expected, there are structural differences between them. In Portugal, the transposition of the EU Directive was concluded only in 2007 (three years after the implementation deadline established by the Directive) through the Decree-Law 232/2007 (national legislation) and is similar to the SEA Directive. Due to the special administrative status of the Portuguese autonomous regions of Azores and Madeira, the Decree-Law allows its adaptation through specific regional legislative procedures by the regional authorities. In 2010, the Azores adapted it through the Regional Decree-Law 30/2010/A (see Polido and Ramos, 2015).

There are two main differences between the national and regional regulations in Portugal. The Regional Decree-Law defines that a small area, in the context of Article 3 (3) of the Directive has 25 hectares $\left(0.25 \mathrm{~km}^{2}\right)$, and introduces the need to climate proof the plan or programme (assessment and internalization of mitigation and adaptation strategies needed due to the potential impacts of global climate change, and its effects at local and regional level, on the plan or programme).

To help with the implementation of the Regulations, the Portuguese Environmental Agency (APA) and the Portuguese Directorate-General for Spatial Planning and Urban Development (DGOTDU) developed guideline manuals outlining the SEA practice in Portugal. The APA guideline manual (Partidário, 2007) has a wide scope and was recently updated (see Partidário, 2012) and the DGOTDU guideline manual (DGOTDU, 2008) is specifically for the SEA of Local Spatial Plans (e.g., master plans; urban plans). The Azorean Regional Directorate for the Environment adopted the guidance published by APA as their SEA guidelines, indicative of the influence from outside agencies rather than the regional and local ones (Ramos et al., 2009), in these territories.

The case of Scotland is very different. Here the Government published the first SEA regulation in 2004 (Jackson and Illsley, 2007) in order to implement the Directive on time. However, the "Scottish

\footnotetext{
${ }^{1}$ The nomenclature "EU SEA Directive" or simply "SEA Directive" in this research paper referrers to the Directive 2001/42/EC of the European Parliament and of the Council of 27 June 2001 on the assessment of the effects of certain plans and programmes on the environment. This Directive has been transposed by all member states of the European Union to domestic legislation (Polido et al., 2014).
} 
Paper published as follows: Polido, A., João, E. and Ramos, T. (2016), Strategic Environmental Assessment practices in European small islands: Insights from Azores and Orkney islands. Environmental Impact Assessment Review ,Volume 57, February 2016, Pages 18-30.

Ministers want[ed] Scotland to be a world leader in [SEA]" (SEEG, 2004, p. 1), and so several consultations and workshops took place to deliver a broader version of the SEA (2004) regulation (McLauchlan and João, 2012). In 2006, the Environmental Assessment (Scotland) Act 2005 (SEA Act (2005)) became mandatory for all the Scottish territory without specific adaptations for different regions/islands.

By covering not only Plans and Programmes as stated in the Directive, but addressing also Strategies, the SEA Act (2005) goes beyond the scope of the Directive and covers almost all aspects of policy formulation in Scotland (Jackson and Dixon, 2006; Kelly et al., 2012). Also, as identified by McLauchlan and João (2012), SEA in Scotland presents a unique SEA stage - the pre-screening where the responsible authority needs to register their intention not to do an SEA that they identify as having "no" or "minimal" effect on the environment (SEA Act (2005), Part 1, 7(1)).

To provide practitioners with the tools to develop SEA, the Scottish Executive issued an SEA toolkit (Scottish Executive, 2006) with detailed guidance where the SEA process is organised and structured (Kelly et al., 2012; Noble et al., 2012; SEPA, 2011). In 2013 the SEA Toolkit was replaced by the "Strategic Environmental Assessment Guidance" (Scottish Government, 2013).

Comparing the guidelines from both SEA system process and procedural frameworks (i.e., Partidário, 2012, 2007; Scottish Executive, 2006; Scottish Government, 2013) it is clear that there are also differences between the two countries. For instance, the Portuguese guidance uses an integrated environmental issue type as assessment topic ${ }^{2}$, while the Scottish practice focus mainly on the environmental issues provided by the Directive or by the SEA objectives established.

Both types of assessment topics provide a yardstick, grounding the assessment, against which the Plan, Programme or, in the Scottish case, Strategy (PPS), integrating the different SEA stages and assessment methods and techniques used, can be assessed. The Portuguese and Scottish guidelines indicate the context-specificity of the assessment techniques, which should be adequate to the type of PPS addressed. Nonetheless, the Portuguese and Scottish guidelines mention the use of "sustainability framework and indicators" (similar to the definition by UNEP (2009)) to set the SEA context and objectives and "trend analysis", and "SWOT analysis" (similar to the definition by UNEP (2009) and Fischer (2007) respectively) for the baseline information and evolution without PPS.

However, the definition used for alternatives vary, as well as the techniques for the assessment of effects. Partidário (2012), proposes "strategic options" instead of "alternatives", whereas in the Scottish guidelines, alternatives should follow a hierarchy (ODPM , 2005; Scottish Executive, 2006) mainly done through "impact matrices" (similar to the definition by Fischer (2007)). Also, in the case of the assessment of effects, the Portuguese guidelines suggest it should be done through "scenario

\footnotetext{
${ }^{2}$ The Portuguese guidelines use the designation "critical factor for decision-making" for the assessment topics, which is defined as "(..) aspects that must be considered in the decision process concerning the strategy design and the implementing actions (...) and are generated out of an integrated analysis of the following elements (...): Strategic Reference Framework (SRF); Strategic issues (SI) (strategic objectives and core principles) of the object of assessment; Environmental factors (EF)" (Partidário, 2007, p.20).

3 "The strategic options are policy or planning options, that help us to move from where we are to where we want to get (...). Strategic options are optional pathways that help us reach our intended long-term objectives, associated with our vision." (Partidário, 2012, p. 38, p. 38).
} 
Paper published as follows: Polido, A., João, E. and Ramos, T. (2016), Strategic Environmental Assessment practices in European small islands: Insights from Azores and Orkney islands. Environmental Impact Assessment Review ,Volume 57, February 2016, Pages 18-30.

analysis", "stakeholder involvement", and the "assessment of opportunities and risks", while in the Scottish guidelines, a different combination of methods could be used, depending on the types of objectives and alternatives, e.g., "matrix based approaches and scoring systems", "mapping and spatial analysis", "criteria based checklists", and "environmental topics based approach".

After the assessment is done, and the PPS is implemented, it is necessary to monitor the actual effects on the environment as well as to identify unforeseen adverse effects. Monitoring is mandatory but regulations fail to provide insights on how this can be done. However, it is important to anticipate and plan how the follow-up will be achieved during the environmental report phase. The Portuguese and Scottish guidelines go beyond regulation providing good practices for SEA follow-up. For instance, the Portuguese guide makes reference to three types of follow-up: performance, conformance, and uncertainty (as defined by Partidário and Fischer (2004)), and use as techniques, indicators (similar to the definition by Fischer (2007)) and stakeholder engagement, while the Scottish guides focus on performance, uncertainty and dissemination, using mainly indicators as techniques for monitoring.

Stakeholder engagement is a key issue in SEA, which should occur in the early stages of the process and include everyone with an interest, or is affected by the PPS (Abaza et al., 2004). The SEA Directive clearly states that to have a more transparent decision-making, and a comprehensive and reliable assessment it is necessary to consult authorities with relevant environmental responsibilities, and the public. It also states that the Member States need to appoint these authorities. However, the techniques used for stakeholder engagement are to be determined by the Member States.

To address these issues, the Portuguese Decree-Law presents an illustrative list of entities with specific environmental responsibilities (e.g. Portuguese Environmental Protection Agency, Portuguese Institute for Nature Conservation and Forests, regional coordination and development commissions, health authorities, municipalities), while the Scottish SEA Act clearly identifies as the consultation authorities, Scottish Ministers (Historic Scotland) ${ }^{4}$ (SPCB, 2005), Scottish Environment Protection Agency, and Scottish Natural Heritage.

According to the SEA Directive, it is mandatory to consult the authorities in the scoping phase as well as in the environmental report phase. The public is only called on to participate in the environmental report phase, even though the Directive states that the public should be "given an early and effective opportunity (...) to express their opinions" (Directive 2001/42/EC, article 6 (2)). Nonetheless, both the Portuguese and Scottish guidelines make reference to the appropriateness of involving other stakeholders, in addition to the authorities named in the legislation, from the scoping stage onwards.

As for techniques to engage stakeholders, neither set of regulations recommend what techniques to use. However, the guidelines provide strategies for the engagement during the early stages, for instance, workshops, social networks or citizen panels. Additionally, the Portuguese guidelines make

\footnotetext{
${ }^{4}$ Due to Historic Environment Scotland Act 2014 and secondary legislation, from 1 October 2015, Historic Scotland will be replaced by Historic Environment Scotland as a Consultation Authority (Scottish Government/Environmental Assessment Team et al., 2015).
} 
Paper published as follows: Polido, A., João, E. and Ramos, T. (2016), Strategic Environmental Assessment practices in European small islands: Insights from Azores and Orkney islands. Environmental Impact Assessment Review ,Volume 57, February 2016, Pages 18-30.

reference to a "governance framework" ${ }^{5}$ as part of the SEA process. The framework should be used to identify different stakeholders, establish relations between them, and their responsibilities with respect to the SEA process.

Aligned with stakeholder engagement is keeping the public and other entities informed, being a major concern within the EU SEA Directive. However, in the Portuguese case, the availability of information is dispersed among APA webpages for different sectors and other governmental agencies. In the case of the Azores, the information is spread among different sections within the Regional Directorate of the Environment website. Additionally, there is also a low representation of Environmental Reports available in APA, compared to the number which were supposed to be available, and there is no reliable way to know how many SEAs were developed in Portugal (Partidário et al., 2010).

The Scottish Government made provisions in their SEA website to provide information on all SEA being developed or already completed, making the information regarding the SEA process accessible for the general public. The documents from the different SEA stages are made available as well as the consultation authorities' responses. As noted by McLauchlan and João (2012), the SEA Act (2005) does not legislate about the availability of the information, but with the commitment to become a leading country in SEA, uniquely the Scottish government made information accessible through the web-based SEA database (see Scottish Government, n.d.).

The Scottish Executive has also created the SEA Gateway Team to operate as a centralised body where the information is gathered and integrated to advise and co-ordinate the process to ensure SEA quality (Jackson and Dixon, 2006; SPCB, 2005). In addition, the Scottish Government SEAdedicated website (see Scottish Government, n.d.), provides specific guidance for the consideration of climatic factors, air, soil and water. All of these initiatives link to Scotland's ambition to be a world leader in SEA.

\section{Methods}

Due to the exploratory nature of the research, an inductive research approach was used. This involved a mixed model research approach employing an embedded multiple-case study (Azores and Orkney archipelagos) (Yin, 2009) and qualitative content analysis to 43 SEA Environmental Reports (ERs) (Mayring, 2000). The 43 SEA ERs include Portuguese and Scottish mainland reports, to contextualise the European small islands case studies. This section presents and justifies the methods used to conduct the research. First, a rationale for using the Azores and Orkney archipelagos is presented, as well as their characterisation. It then provides the Environmental Reports (ERs) selection justification and finally, explains how the content analysis was developed.

\subsection{Two-case study approach: The Azores and Orkney archipelagos}

Case study is a systematic research strategy which investigates phenomena, emphasising an understanding of how processes are influenced, and how they influence context (Hartley, 2004; Yin,

\footnotetext{
${ }^{5}$ Governance framework is defined as "a network of inter-related government and non-governmental organizations and institutions, including citizen panels or other forms of citizen deliberative organizations" (Partidário, 2012, p. 38).
} 
2009). In this research, an embedded multiple-case study was conducted using the methodological guidelines developed by Yin (2009), following a literal replication logic, meaning that the selection of the case studies predicts similar results since they share similar core characteristics (e.g. small size, geographic isolation, a narrow economic base, limited resources, and ecosystems vulnerable to other external ecological influences (see Section 1)), even though there are some differences between these two archipelagos. Following this, the rationale for the choice of Azores and Orkney as case studies, as well as the characterisation of the case studies, is presented.

\subsubsection{Rationale for Azores and Orkney as case studies}

To develop this research it was necessary to choose case studies that had a well-established SEA system with SEA reports available. As shown by Fischer and Onyango (2012), the European Union (EU) is the area most covered by research projects on SEA, probably due to the well-established SEA system (the SEA Directive, as referred in Section 2). Therefore, the first criterion was that the small islands had to be an EU member state or be part of an EU member state.

From the countries stated in the Fischer and Onyango (2012) research, it was understood that Portugal offered an opportunity to study a European Outermost Region ${ }^{6}$, either Madeira or the Azores. The Azores was chosen, rather than Madeira, due to their unique geographic location (isolated in the North Atlantic, on the Mid-Atlantic Ridge) and their specific SEA legislation.

Also, Fischer and Onyango (2012), showed that the EU SEA research projects mainly focused on the UK. The UK has several small islands but since the Scottish Government is committed to becoming SEA world leader and the Scottish SEA Act (2005) goes beyond the scope of the Directive, covering Strategies, Plans and Programmes, it was decided to choose an island or archipelago within Scotland to represent the UK. Looking further into the Scottish territorial system it was decided to have an island that represented an area council. The Orkney Islands were therefore chosen because they are a Scottish council area, have the smallest area and the highest population density within the Islands Council areas of Scotland. Figure 1 shows the Azores and Orkney archipelago locations.

\footnotetext{
${ }^{6}$ The European outermost regions are addressed in the Treaty on the Functioning of the European Union (TFEU), articles 349 and 355.
} 


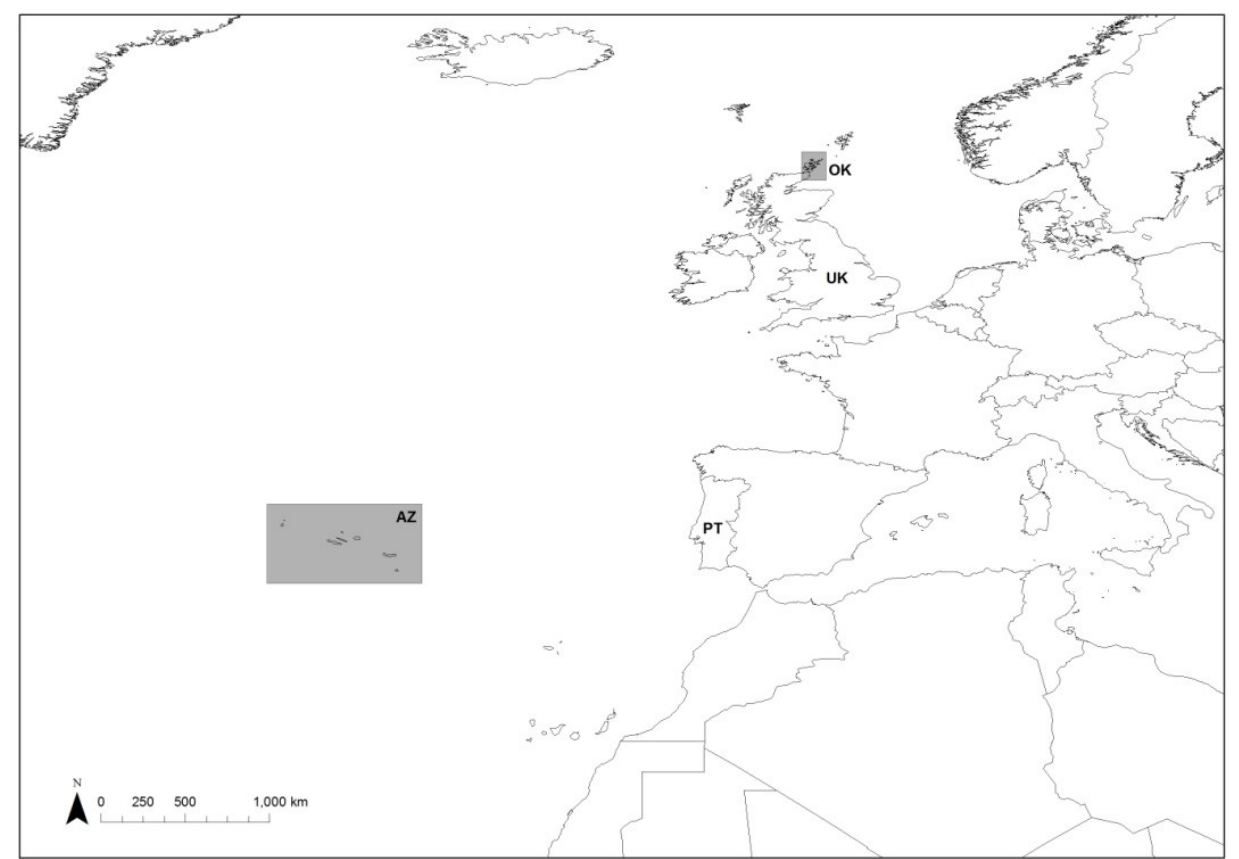

Source of official administrative boundaries: Eurostat (2014) (@ EuroGeographics for the administrative boundaries) Note: AZ: Azores; OK: Orkney; PT: Portuguese Mainland; UK: United Kingdom mainland

Figure 1 - Location of Azores and Orkney Archipelagos

\subsubsection{Characterisation of Azores Archipelago}

The Azores is a Portuguese autonomous region with its own political-administrative statutes and government bodies. This political regime was established in Título VII of the Portuguese Constitution. The autonomy of the archipelago is based on the geographical, economic, social, natural characteristics, and the historical aspirations for autonomy of the populations of the islands (Suárez de Vivero, 1995).

The archipelago is constituted by nine inhabited islands, divided into three groups: western group (Corvo and Flores islands), central group (Graciosa, Terceira, São Jorge, Pico and Faial islands), and an eastern group (São Miguel and Santa Maria islands) (Figure 2), distributed along $600 \mathrm{~km}$ with an Exclusive Economic Zone (EEZ) of approximately $984,300 \mathrm{~km}^{2}$ and a coastline of $690 \mathrm{~km}$ (Borges et al., 2009). The islands are of volcanic origin and are located on the Mid-Atlantic Ridge, a tectonically and volcanically active region (Andrade et al., 2006; Borges et al., 2002; Calado et al., 2011a, 2011b), in the middle of the North Atlantic. Ponta Delgada, on São Miguel island, is the capital of the archipelago, and is approximately 1,500 km from Lisbon. Corvo is the smallest island with $17 \mathrm{~km}^{2}$ of land area and 430 inhabitants, whereas São Miguel is the largest with $745 \mathrm{~km}^{2}$ of land area and 137,830 inhabitants. In total the archipelago has a land area of 2,322 km², and in 2011 had 246,746 inhabitants (DGT, 2014; SREA, 2012).

Azores have high biologic and geologic diversity, reflected by 452 endemic species and about $24 \%$ of the terrestrial territory has been designated a protected area. In the scope of the nine Islands Natural Parks, there are 123 protected areas (terrestrial and marine) and in the scope of the Azores Marine Park there are 11 protected areas (representing ca. 11\% of the EEZ). In the archipelago there are three Biosphere Reserves (Corvo, Flores and Graciosa islands) and two World Heritage sites (DRA et al., 2014). 
The regional economy depends highly on the public sector, but also on the traditional sectors, such as, agriculture and fisheries, particularly livestock production and its related industries. Tourism appears to be an emerging sector (SRAF, 2011). National and European structural funds are central to the development of the region (Carvalho et al., 2011).

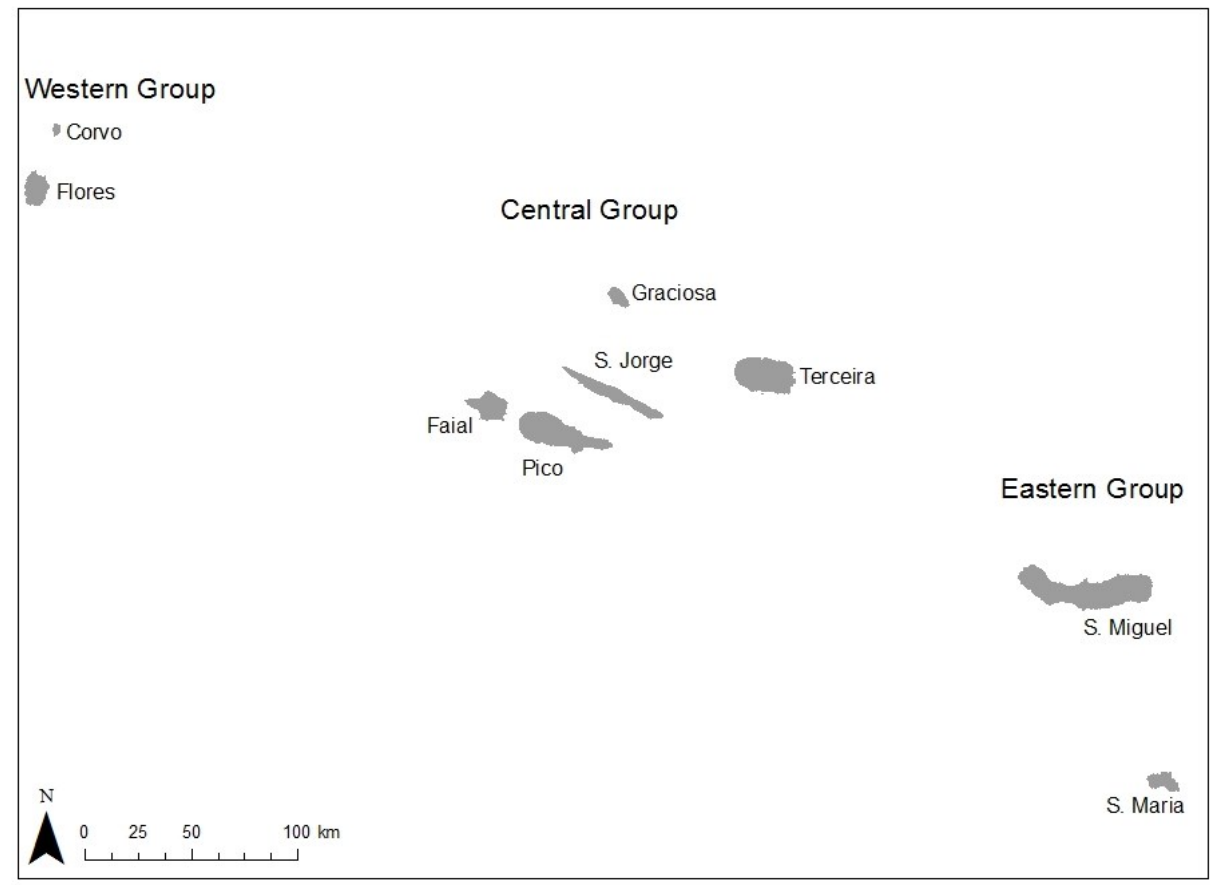

Source of official administrative boundaries: DGT (2014)

Figure 2 - Azores Archipelago

\subsubsection{Characterisation of Orkney Archipelago}

Orkney is a Scottish council area, located $32 \mathrm{~km}$ north from the Scottish mainland, made up of more than 70 islands and islets (Orkney Islands Council, 2012) (Figure 3) but only 20 have full-time residents (National Records of Scotland, 2013a). Orkney was formed through the collision of continents, and are predominantly built from accumulated sediments dating from the Devonian period (McKirdy, 2010).

In 2011, Orkney had a population of 21,349 inhabitants, an area of approximately $990 \mathrm{~km}^{2}$ (National Records of Scotland, 2013b) and a total length of coastline of over $980 \mathrm{~km}$ (Orkney Islands Council, 2012). The least populated island is Inner Holm with a population of 1 inhabitant and the most inhabited is Mainland of Orkney with 17,162 inhabitants (National Records of Scotland, 2013a). Kirkwall, in Mainland of Orkney, is the capital of the archipelago.

The biologic and geologic diversity is reflected in the 73 international and national protected areas: six special areas of conservation, 13 special protection areas, 36 sites of specific scientific interest, one Ramsar site, one local nature reserve, and 16 geological conservation review sites (of these, 12 are also Sites of Special Scientific Interest - SSSIs) (Orkney Islands Council, 2012). Furthermore, Orkney is home to a World Heritage site - The Heart of the Neolithic, due to their prehistoric cultural landscape dating from ca. 5,000 years ago. 
The Orkney economy is reliant on tourism and has a high percentage of employment in the health and social work, wholesale and retail trades, construction, and agricultural, forestry, and fishing, sectors (Highlands and Islands Enterprise, 2014; Orkney Islands Council, 2007). Additionally, beef cattle farming, fishing, salmon farming, and the ferry operation are central in the development of the local economy (Orkney Islands Council, 2007).

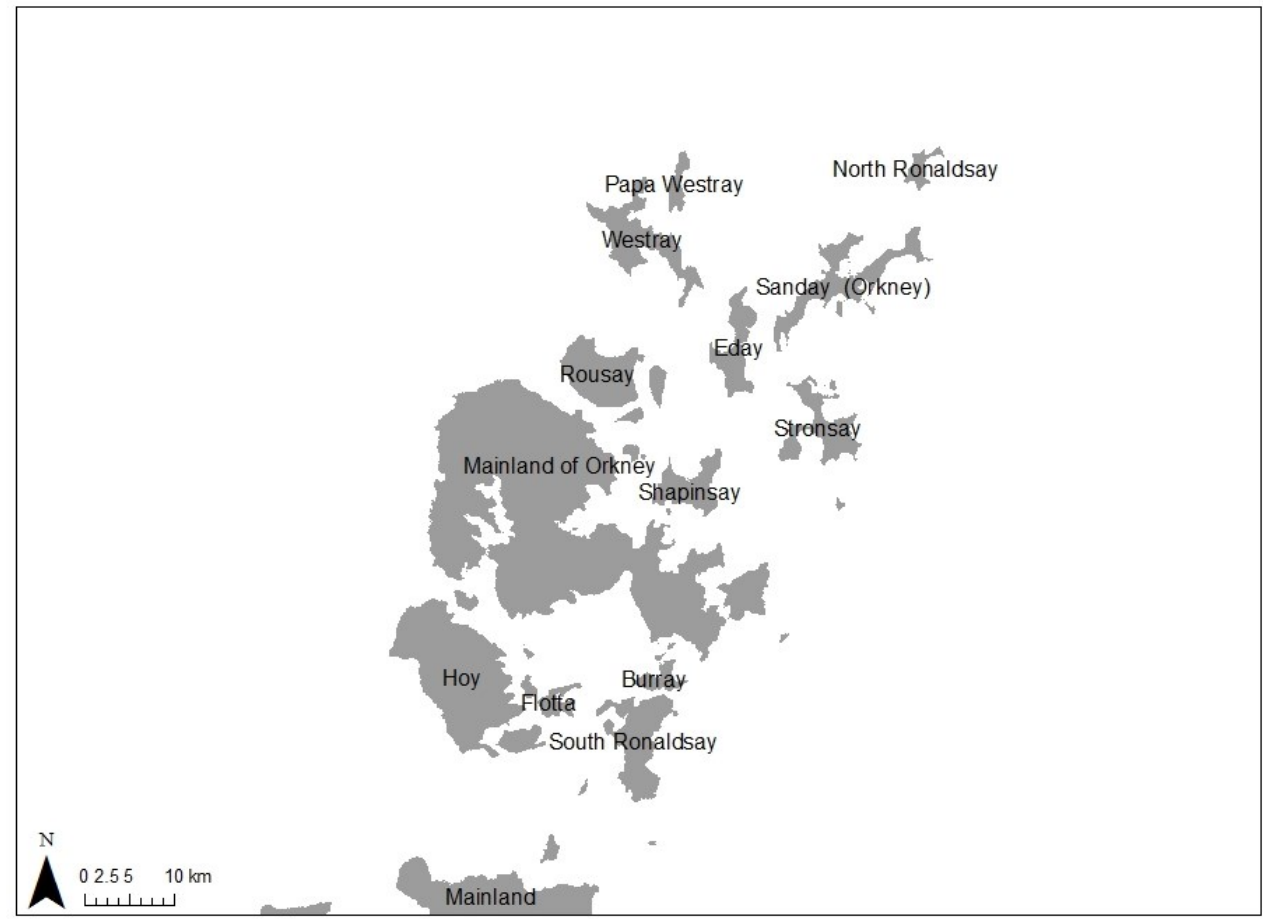

Source of official administrative boundaries: National Records of Scotland (2013c) (๔ Crown copyright and database right 2013) Figure 3 - Orkney Archipelago

\subsection{Environmental reports selection}

The selection of the SEA ERs took into account the scope of the research. The Azorean and Orkney ERs were chosen using the following criteria:

(i) Availability in the institutional webpages (Azorean Government and Scottish SEA Database);

(ii) SEA process with, at least, final ERs and/or post-adoption statements, and;

(iii) For the Azores, the ER from regional spatial plan, special spatial plan (environmental protection related plans) or sectoral plan or programmes (PP); for the Orkney case, plans, programmes or strategies (PPS) affecting the council area, to reflect that island as the spatial unit.

For the mainland, ERs selection followed the pre-requisite that they had to be similar to the ERs retrieved for the islands, to allow comparison between the island context and the mainland. However, in the Portuguese mainland case, due to the administrative specificities, the correspondent institutional webpage is the Portuguese Environmental Agency.

The sample collection was conducted from January to July 2013. A total of 43 cases were retrieved 7 from the Azores and 14 from the Portuguese mainland; 5 from Orkney and 17 from the Scottish 
mainland. Table 1 summarises the Environmental Reports used in the content analysis (for a detailed characterisation see Appendix 1).

Table 1 - Environmental Reports included in the content analysis

\begin{tabular}{|c|c|}
\hline Code & Plan or Programme title \\
\hline \multicolumn{2}{|c|}{ Azorean Environmental Reports } \\
\hline A1 & PROT Azores \\
\hline A2 & POOC Santa Maria \\
\hline$A 3$ & POOC Corvo \\
\hline A4 & POOC Flores \\
\hline A5 & POOC Graciosa \\
\hline A6 & POOC Pico \\
\hline A7 & PGRH Azores \\
\hline \multicolumn{2}{|c|}{ Portuguese Mainland Environmental Reports* } \\
\hline PM1 & PROT Oeste e Vale do Tejo \\
\hline PM2 & PROT Alentejo \\
\hline PM3 & PROT Norte \\
\hline PM4 & PROT Área Metropolitana Lisboa \\
\hline PM5 & PROT Centro \\
\hline PM6 & PGRH Ribeiras do Algarve \\
\hline PM7 & PGRH Sado e Mira \\
\hline PM8 & PGRH Guadiana \\
\hline PM9 & PGRH Ribeiras do Oeste \\
\hline PM10 & PGRH Tejo \\
\hline PM11 & PGRH Minho e Lima \\
\hline PM12 & PGRH Douro \\
\hline PM13 & PGRH Cávado, Ave e Leça \\
\hline PM14 & PGRH Vouga, Mondego e Lis \\
\hline \multicolumn{2}{|c|}{ Orkney Environmental Repots } \\
\hline 01 & Orkney Islands Local Transport Strategy \\
\hline $\mathrm{O} 2$ & Community Plan \\
\hline 03 & Local Biodiversity Action Plan \\
\hline $\mathrm{O} 4$ & Sustainable Energy Strategy \\
\hline 05 & The Orkney Plan \\
\hline \multicolumn{2}{|c|}{ Scottish Mainland Environmental Reports } \\
\hline SM1 & Glasgow Local Transport Strategy - 'Keeping Glasgow Moving' \\
\hline SM2 & Dumfries and Galloway Local Biodiversity Action Plan (Second Edition) \\
\hline SM3 & North Ayrshire Local Transport Strategy \\
\hline SM4 & Renfrewshire Local Transport Strategy 2006 \\
\hline SM5 & West Dunbartonshire Council Local Transport Strategy \\
\hline SM6 & Review of the Ayrshire Local Biodiversity Action Plan \\
\hline SM7 & East Dunbartonshire Local Plan 2 \\
\hline SM8 & East Lothian Biodiversity Action Plan 2008 to 2013 \\
\hline SM9 & East Renfrewshire Council Local Transport Strategy \\
\hline SM10 & Highland Coastal Development Strategy \\
\hline SM11 & Dunbartonshire Biodiversity Action Plan \\
\hline SM12 & Highland wide Local Development Plan \\
\hline SM13 & Moray Council Draft Local Transport Strategy \\
\hline SM14 & South Lanarkshire Local Biodiversity Action Plan \\
\hline SM15 & Fife Community Plan 2011-2020 \\
\hline SM16 & East Ayrshire Community Plan \\
\hline SM17 & Perth \& Kinross Council's Community Plan \\
\hline
\end{tabular}

Note: PGRH - River basin district Management Plan | POOC - Coastal Zone Spatial Plan | PROT - Regional Spatial Plan *There were no POOC SEAs available for the Portuguese mainland when the research was conducted.

\subsection{Qualitative content analysis}


Paper published as follows: Polido, A., João, E. and Ramos, T. (2016), Strategic Environmental Assessment practices in European small islands: Insights from Azores and Orkney islands. Environmental Impact Assessment Review ,Volume 57, February 2016, Pages 18-30.

The data collection for comparison of the practices used in Azores, Portuguese mainland, Orkney and Scottish mainland was accomplished through a qualitative content analysis based-approach of the SEA ERs according to the methodological recommendations of Bardin (1977), Krippendorff (2003) and Mayring (2000). Content analysis is a systematic approach used to collect data from documents (Bardin, 1977) allowing replicable and valid inferences from texts (Krippendorff, 2003). The limitations of the method are mainly associated with the documents analysed, which can pose problems of credibility, authenticity, representativeness and availability (Bryman, 2012). Nonetheless, content analysis allows the research to have the flexibility needed in exploratory studies, and enhances research transparency and reduces subjectivity (Bardin, 1977; Bryman, 2012).

To develop the qualitative content analysis, a criteria set of five items was established, related to the core elements found in the literature (see Sections 1 and 2). The analytical objectives were also added to the framework to establish the analysis boundaries. The ERs used as the primary data source (see Section 3.2.) were read and analysed iteratively against it.

Table 2 summarizes the criteria framework used. These cover the guidelines used to operationalize the institutional and procedural framework, the assessment topics studied, the adopted assessment techniques and methodological approaches, and the stakeholders' engagement process.

Table 2 - Content analysis framework: criteria, rationale and objectives for the analysis done to the environmental reports.

\begin{tabular}{|c|c|c|c|}
\hline Criteria & Rationale & Analysis objectives & Adapted from \\
\hline Guidelines & $\begin{array}{l}\text { The purpose of this criterion is to help } \\
\text { understand what is the procedural } \\
\text { guidance framework adopted in the ERs. } \\
\text { Also, if SEA is context specific, it is } \\
\text { important to understand if there are } \\
\text { differences between the systems and } \\
\text { between the islands and the mainland. }\end{array}$ & $\begin{array}{l}\text { Identify guidelines used (e.g., APA } \\
\text { (2007), Scottish Executive (2006)). }\end{array}$ & $\begin{array}{l}\text { Chaker et al. } \\
\text { (2006) } \\
\text { Noble et al. } \\
\text { (2012) } \\
\text { Rachid and El } \\
\text { Fadel (2013) }\end{array}$ \\
\hline Assessment topics & $\begin{array}{l}\text { This criterion aims to analyse if islands } \\
\text { ERs address similar environmental/ } \\
\text { sustainability issues to the ones used in } \\
\text { the ERs from the mainland. } \\
\text { Furthermore, this criterion helps to } \\
\text { establish typical sustainability issues to } \\
\text { be studied in future SEA of small islands. }\end{array}$ & $\begin{array}{l}\text { Identify environmental/ sustainability } \\
\text { issues used in ER (e.g., environmental/ } \\
\text { sustainability issues of the EU Directive, } \\
\text { aggregated sustainability issues, } \\
\text { strategic sustainability issues). } \\
\text { Identify the typical sustainability issues } \\
\text { used in the assessment in small islands } \\
\text { versus mainland (e.g., are there topics } \\
\text { more used in small islands than in the } \\
\text { mainland). }\end{array}$ & $\begin{array}{l}\text { Abaza et al. } \\
\text { (2004) } \\
\text { Fischer (2002) } \\
\text { Therivel (2004) }\end{array}$ \\
\hline $\begin{array}{l}\text { Assessment } \\
\text { techniques and } \\
\text { methodological } \\
\text { approaches }\end{array}$ & $\begin{array}{l}\text { The aim of this criterion is to analyse the } \\
\text { different assessment techniques used in } \\
\text { the ERs, and to correlate the assessment } \\
\text { techniques with steps of the assessment } \\
\text { where they were used. This helps to } \\
\text { understand what are the current } \\
\text { methodological approaches used. Plus, } \\
\text { to relate these to the context-specificity } \\
\text { (small islands vs. mainland) of the } \\
\text { different SEA systems. }\end{array}$ & $\begin{array}{l}\text { Identify assessment techniques (e.g., } \\
\text { trend analysis, impact matrix, expert } \\
\text { judgement). } \\
\text { Identify where each technique was used } \\
\text { in the assessment (e.g., baseline } \\
\text { information, alternatives, effects } \\
\text { prediction and evaluation). }\end{array}$ & $\begin{array}{l}\text { Fischer (2007) } \\
\text { Noble et al. } \\
\text { (2012) } \\
\text { OECD (2006) } \\
\text { Therivel (2004) } \\
\text { UNEP (2009) }\end{array}$ \\
\hline
\end{tabular}




\begin{tabular}{|c|c|c|c|}
\hline Criteria & Rationale & Analysis objectives & Adapted from \\
\hline Follow-up & $\begin{array}{l}\text { Follow-up helps measure how the } \\
\text { sustainability inputs are influencing the } \\
\text { post-implementation of the decision- } \\
\text { making. It is important to plan the } \\
\text { follow-up stage in order to allocate } \\
\text { responsibilities and ensure a follow-up } \\
\text { programme. The analysis also focuses on } \\
\text { how this is different for each } \\
\text { archipelago. }\end{array}$ & $\begin{array}{l}\text { Identify the type of follow-up proposed } \\
\text { (e.g., conformance, performance). } \\
\text { Identify if it establishes who is } \\
\text { responsible for the follow-up (e.g., } \\
\text { authority responsible for plan, } \\
\text { independent third party, stakeholders). }\end{array}$ & $\begin{array}{l}\text { Fischer (2007) } \\
\text { Morrison- } \\
\text { Saunders et al. } \\
\text { (2014) } \\
\text { Nilsson et al. } \\
\text { (2009) } \\
\text { Partidário and } \\
\text { Fischer (2004) }\end{array}$ \\
\hline $\begin{array}{l}\text { Stakeholder } \\
\text { engagement }\end{array}$ & $\begin{array}{l}\text { Stakeholder engagement is paramount } \\
\text { for the development of an effective SEA } \\
\text { and to enhance sustainability in small } \\
\text { islands. Hence, it is necessary to } \\
\text { understand how the ER addresses it in } \\
\text { the small islands and compare with the } \\
\text { practices of the mainland. }\end{array}$ & $\begin{array}{l}\text { Identify if and which stakeholders were } \\
\text { contacted (e.g., lists of stakeholders). } \\
\text { Identify how stakeholders were } \\
\text { engaged, which techniques were used } \\
\text { (e.g., participatory forums, dedicated } \\
\text { website, written opinions issued by } \\
\text { entities with responsibilities in the plan } \\
\text { or program development). }\end{array}$ & $\begin{array}{l}\text { Gauthier et al. } \\
\text { (2011) } \\
\text { IAIA (2002) } \\
\text { Ren and Shang } \\
\text { (2005) } \\
\text { van Doren et al. } \\
\text { (2013) }\end{array}$ \\
\hline
\end{tabular}

The data collected were then analysed, and for each criterion, information was grouped and regrouped, until there were usable units of analysis. In the case of the identification of guidelines, it was possible to group by type of guideline used (national, international/mixed and team's own approach). For the assessment topics, it was necessary to cluster similar types (see Table 3). In the case of the assessment techniques, it was necessary to group the findings of the content analysis into categories which were well known, hence, the definitions of the different assessment techniques, such as, "sustainability framework and indicators", "expert or team judgement", "trend analysis", given by Fischer (2007), OECD (2006), Therivel (2004), and UNEP (2009) were used. Followup was analysed against the four types proposed by Fischer (2007) and Partidário and Fischer (2004): conformance, performance, uncertainty, and dissemination.

At the same time, some of the data collected were quantified. Even though the content analysis is qualitative, it is possible to quantify some of the information, as noted by Saunders et al. (2009). While analysing the data collected, and in order to enhance its description and presentation (Saunders et al., 2009), absolute frequencies were used, helping improve the comparison between these exploratory islands case studies and the mainland.

\section{Results and findings}

This section presents the results and findings from the qualitative content analysis done to the SEA Environmental Reports (see Table and Appendix 1), the two-case studies and the Portuguese and Scottish mainland reports, which helped establish their context. This section is structured according to the criteria used to develop the analysis: (i) the guidelines used, (ii) the environmental and sustainability issues assessed, (iii) the assessment techniques and methodological approach employed, (iv) the follow-up envisaged and (iv) the stakeholder engagement performed.

\subsection{Guidelines}


Paper published as follows: Polido, A., João, E. and Ramos, T. (2016), Strategic Environmental Assessment practices in European small islands: Insights from Azores and Orkney islands. Environmental Impact Assessment Review ,Volume 57, February 2016, Pages 18-30.

The sample of Portuguese mainland (PT mainland) ERs analysed show that 10 out of 14 followed national guidelines and/or regulations. Of these 10, three followed the APA guidelines strictly (PM1, PM3 and PM4), six were done with a combination APA guidelines and national regulations (PM6, PM7, PM8, PM9, PM10 and PM14) and only PM13 followed "good practice and recent national experience in SEA" but not the APA guidelines. It needs to be noted that the three ERs that followed the APA guidelines strictly (Partidário, 2012, 2007) were coordinated by that author (see Appendix 1).

The four remaining PT mainland ERs, from the 14 analysed, used a combination of international and national guidelines. Nonetheless, PM2 only mentions international guidance and practices, but it also follows the national regulations. Additionally, PM5, PM11 and PM12 state they are using methodological guidelines different from national and international experience, presenting the same references.

Even though the Azorean Regional Directorate for the Environment adopted the guidance published by APA as their SEA guidelines (Partidário, 2012, 2007), as seen in Section 2, none of the Azorean ERs used them per se. Similarly to PM13, A7 states the report is done "in line with good practice and recent national experience in SEA", and it is the only report which refers to the Azorean-specific legislation, since it was completed after these regulations came into force. The ERs A1 and A6 make reference to the same methodological guidelines from national and international experience as PM5, PM11 and PM12. The ERs A2, A3, A4 and A5 were done by the same team, presenting the same structure, and presenting their own approach to SEA, grounded by the national regulations.

These results are in line with the findings of the review conducted by Partidário et al. (2010), where the majority of the Portuguese ERs did not follow the APA guidelines, following instead a combination of national and international guidance. Furthermore, the Portuguese SEA teams tend to systematically use the same type of guidance and structure to develop the ERs, indicating that the approaches used are dependent on the team doing the SEA rather than the type of PP addressed. Overall, only four ERs presented a specific approach for the island report, and it must be highlighted that the reports were done by an academic team from the archipelago (Universidade dos Açores).

In the Scottish case there was a lack of diversity in structure and guidance, not reflecting specific contexts. In the Scottish mainland (SCT mainland), the majority of the reports also used the template or made a specific reference to the SEA (Scotland) Act 2005, only 3 out of the 17 ERs from the mainland analysed had a different outcome. The SM8 had a shorter version, not making references to the regulations or the SEA template, and perceived as the SEA team's own approach. In the case of SM9 and SM13 references are made to guidance different from the Scottish regulations and toolkit, respectively, to ODPM (2005) and to Therivel (2004), and was perceived as a combination of international and national guidance. In the ERs analysed for the Orkney archipelago, all ERs used the template provided by the Scottish Government (2013).

\subsection{Assessment topics}

The analysis showed a wide variety of terms used for the assessment topics because different reports used different designations for the same type of issue assessed. It was possible to group similar assessment topics for the analysis (see Table 3). Also, while analysing the ERs it was possible 
to categorise different clusters of assessment topics into: (i) aggregated Directive topics ${ }^{7}$ (type 1 ), if an ER used the Directive topics combined with other topics, e.g. biodiversity, fauna and flora; (ii) strategic sustainability issues (type 2), if an ER used assessment topics that derived from a mixed approach with different entry points, including but not limited to, PPS objectives, relevant international and national PPS objectives, inputs from stakeholders; and, (iii) other type of assessment issues (type 3), if an ER did not use one of the previous types, but a different approach. Table 3 presents the groups used for the assessment topics categorised by type of assessment topics used.

Table 3 - Clustered assessment topics (with the variety of terms used in Environmental Reports, grouped by theme) and codes used in this paper

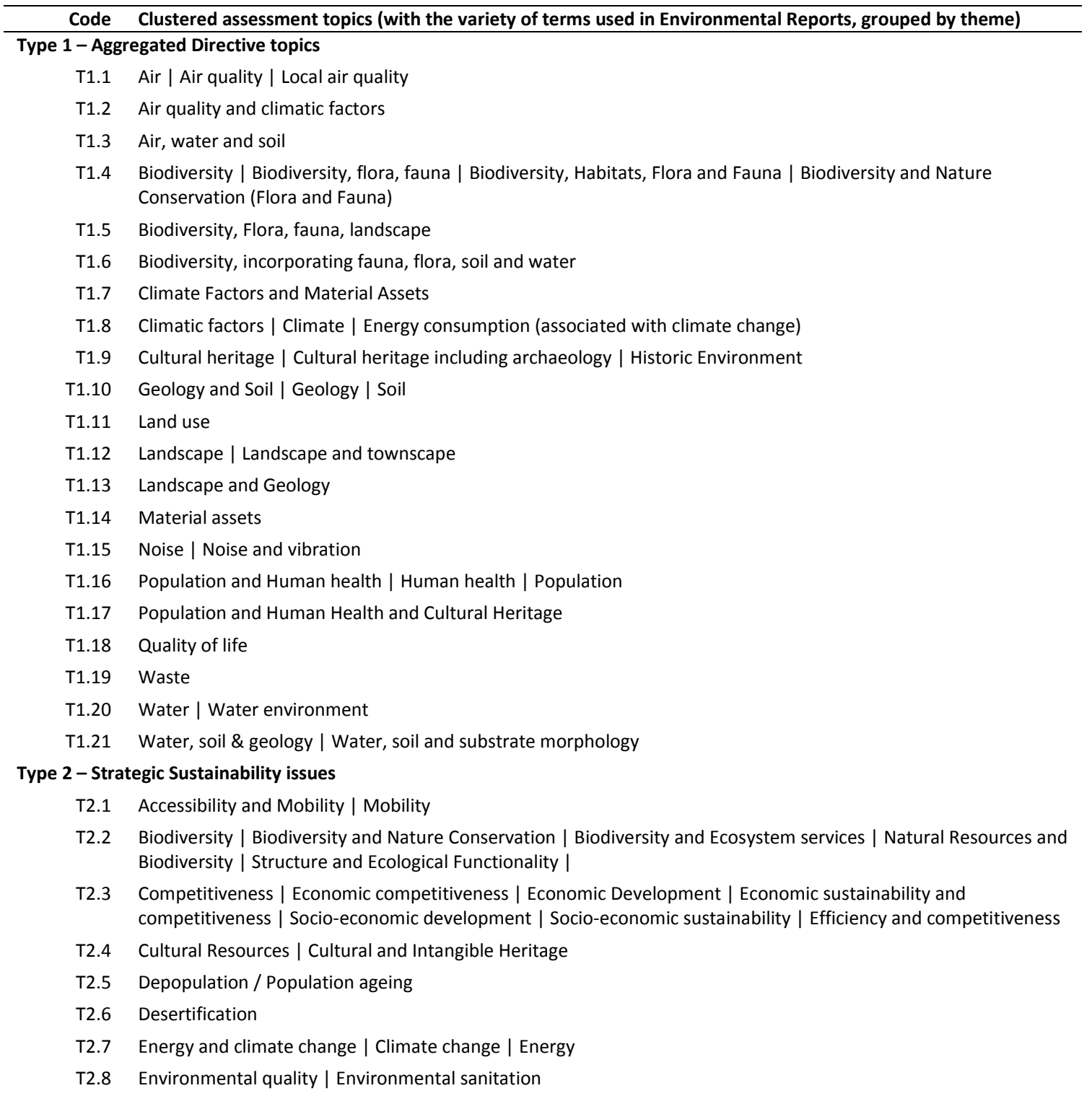

${ }^{7}$ Directive 2001/42/CE: Article 5(1) and Annex 1, (f) the likely significant effects(1) on the environment, including on issues such as biodiversity, population, human health, fauna, flora, soil, water, air, climatic factors, material assets, cultural heritage including architectural and archaeological heritage, landscape and the interrelationship between the above factors. 


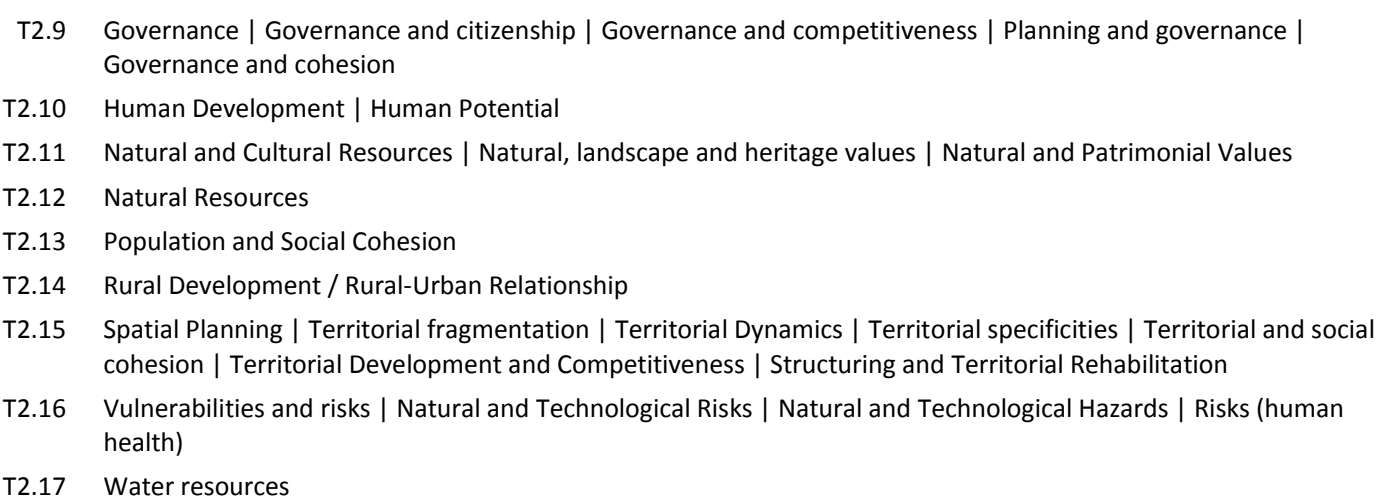

\section{Type 3 - Other type of assessment issues}

The assessment was conducted through issues different from type 1 and type 2 assessment topics, e.g. programmes envisaged in the Plans, SEA objectives.

Note: the assessment topics were clustered for each code by content and similarity of terminology. Even though some codes may seem similar, they represent a different assessment topic, which was placed under a different code for the purpose of analysis transparency.

The analysis showed that the Portuguese ERs, mainly used "strategic sustainability issues" (type 2) while the Scottish ERs mainly used "aggregated Directive topics" (type 1). Eight ERs used another type of assessment issues: four Azorean ERs and four SCT mainland ERs. In the case of the Azores, these are the same ERs that were made by the SEA team's own approach (A2, A3, A4 and A5) and used the programmes envisaged in the Plans to do the assessment. The SCT mainland ERs with specific assessment topics are SM1, SM3, SM9 and SM12. In the case of SM1, the report added to the assessment topics from the Directive, social issues (crime and social exclusion), hence, it was categorised as "other type assessment topic" (type 3). In the other three ERs, the assessment was developed based on the SEA objectives.

This is consistent with the findings from the previous section, where the majority of the Portuguese ERs used a mix of national and international guidelines, while the Scottish ERs largely used the SEA template (see Scottish Executive, 2006). This follows a Directive-based approach. It was therefore expected that these reports would use environmental issues stated in the Directive, but the SEA teams aggregated the topics into sets of complementary information (e.g., biodiversity, fauna and flora; air and climatic factors, population and human health).

Of the 14 Portuguese mainland ERs, 11 used assessment topics related with vulnerabilities and risks (T2.16), 10 ERs used assessment topics related with spatial planning (T2.15), 8 ERs with Biodiversity (T2.2), socio-economic sustainability and competitiveness (T2.3), and governance (T2.9).

In the three Azorean ERs that used type 2 assessment topics (A1, A6 and A7), the most used topics ( 3 out of 3 reports) were issues related with socio-economic sustainability and competitiveness (T2.3) and with vulnerabilities and risks (T2.16). Following, in 2 out of 3 reports, there are assessment topics related with energy and climate change (T2.7), environmental quality and sanitation (T2.8) (ERs A1 and A6), governance (T2.9), and spatial planning (T2.15) (ERs A1 and A7).

Despite the Azorean low sample number, it is noted that, these reports focused more than the PT mainland ERs on (i) climate change and energy (only 4 out of 14 PT mainland reports: PM1, PM2, PM4 and PM5), and (ii) environmental quality and sanitation related topics reports (2 out of 14 PT mainland reports: PM1 and PM5). Furthermore, the two Azorean ERs focusing on these topics are 
Paper published as follows: Polido, A., João, E. and Ramos, T. (2016), Strategic Environmental Assessment practices in European small islands: Insights from Azores and Orkney islands. Environmental Impact Assessment Review ,Volume 57, February 2016, Pages 18-30.

related with regional spatial planning and coastal management, and the PT mainland ERs are related with regional spatial planning.

As for the SCT mainland ERs and Orkney ERs, all used similar assessment topics, which covered all issues from the Directive, even though with some different designations. However, it is noted that issues related with climatic factors (T1.8) are used in all Orkney ERs, while in the SCT mainland ERs only 8 out of 13 use it, and air quality related issues (T1.1, T1.2 and T1.3) are less used in the SCT mainland ERs (only present in 4 out of 13), while in the Orkney ERs it is present in 3 out of 5 ERs. Even though, as happens with the Azorean and PT mainland ERs, there is a lower representation of Orkney ERs proportionally to the SCT mainland reports, these differences are easily highlighted.

\subsection{Assessment techniques and methodological approaches}

The Portuguese reports, with the exception of PM4, presented a section with the establishment of context and objectives. The most used technique was "sustainability framework and indicators". However, in the A2, A3, A4, A5, PM5, PM11, PM12 and PM13 cases a complementary technique was used: "expert or team judgement". In the Azorean ERs, it is noted that these ERs are those that used an "SEA team own approach" in "Guidelines" (see section 4.1). As for the Scottish case, only four SCT mainland (SM3, SM5, SM6, SM9) and two Orkney ERs (O1 and O3) presented the context and objectives. The ERs 01, O3, SM6 and SM9 used "sustainability framework and indicators" and SM3 and SM5 used "stakeholders" to define the context and objectives.

In the "Baseline information and likely evolution without the PPS", the majority of the reports used the "trend analysis" technique. However, the four Azorean ERs that had an "SEA team own approach" in the "Guidelines" (see Section 4.1) (A2, A3, A4, and A5), O5 and SM8 did not present this phase in the report. The ER O5 did not present this phase because it was already a second assessment. One report (SM7) presented the trend analysis through an impact matrix. However, it is not clear how this matrix was achieved. SWOT analysis (strengths, weaknesses, opportunities and threats) was used as an additional technique in some PT mainland ERs (PM1, PM3, PM4, PM9, PM10, and PM14) and only OT (opportunities and threats) in two SCT mainland ERs (SM9 and SM11).

As for the assessment of alternatives, it is noted in the Portuguese case that only two PT mainland ERs (PM9 and PM10) presented them using "stakeholders" as the technique for their assessment. Contrasting with these results is the Scottish ERs, where 13 out of 22 assessed alternatives using an "impact matrix" assessment technique (assumed for the following reports: 02, 04, SM6, SM7, SM9, and SM12, because they do not present the matrix, only describe the results). Of these 13 , four are Orkney ERs, where only 05 did not assess alternatives. In the SCT mainland ERs, four did not assess alternatives (SM2, SM8, SM15, and SM16). Furthermore, four SCT mainland reports, relating to transport strategies, used the Scottish Transport Appraisal Guidance (STAG) (see Transport Scotland, $2013,2008)$ (SM1, SM3, SM4, and SM5) to assess them.

In the assessment of the effects phase in the ERs, it is found that a more diverse set of techniques are used, mainly for the Portuguese ERs. The "impact matrix" was the most used technique, only six PT ERs did not use it (A1, A7, PM1, PM3, PM4, and PM5). Also, some reports used other techniques 
Paper published as follows: Polido, A., João, E. and Ramos, T. (2016), Strategic Environmental Assessment practices in European small islands: Insights from Azores and Orkney islands. Environmental Impact Assessment Review ,Volume 57, February 2016, Pages 18-30.

to complement the analysis; this is the case of $A 2, A 3, A 4$, and $A 5$, which used "expert judgement" and "stakeholders". An "ad-hoc expert judgement technique", because it is implicit but not evident, was used in other, seven, PT ERs (A1, A7, PM2, PM5, PM9, PM10, and PM14). The technique "SWOT analysis" was used in $A 1$ and $A 6$ and a shorter version of this technique (OT) was used in other, nine, ERs (A7, PM1, PM3, PM4, PM5, PM9, PM10, PM11 and PM12).

To complement the assessment compatibility matrices and scenario analysis were also used: Compatibility analysis was used in 9 out of 14 PT mainland ERs (PM1, PM3, PM4, PM6, PM7, PM8, PM11, PM12, and PM13), 2 out of 7 Azorean ERs (A6 and A7), and 8 out of 17 SCT mainland ERs (SM1, SM3, SM4, SM9, SM12, SM13, SM14, and SM17). Scenario analysis was only present in Portuguese ERs (A7, PM1, PM4, PM9, and PM10).

In the framework for a proposed follow-up, when present, "indicators" were the assessment technique preferred. The detailed findings for the "proposed follow-up" phase will be presented in the following Section.

Comprehensively, it is possible to say that the Portuguese ERs (from the mainland and Azores) develop and present the context and objectives of the assessment through "sustainability framework and indicators", the baseline information and likely evolution without the PP is grounded by "trend analysis", and follow-up relies on "indicators". However, in the assessment of effects the Azorean ERs rely highly on "impact matrices", "expert judgement", and "stakeholders", while the PT mainland ERs mainly use "impact matrices", "SWOT", and "compatibility analysis". Alternatives, as defined in the Regulations, were not assessed.

As for the Scottish case, both Orkney and mainland, the baseline information and likely evolution without the PPS was accomplished through "trend analysis", alternatives were assessed based on "impact matrices", the assessment of effects were addressed through "impact matrices", and in a few mainland cases "compatibility matrices" were used to complement the analysis. When present, follow-up used "indicators" as the main technique.

Overall, all ERs used a mixed set of methods throughout the assessment, and the types of assessment technique and methodological approach mainly depends on the SEA system and the phase of the ER in which they are applied.

\subsection{Follow-up}

Using the definitions of different types of follow-up by Partidário and Fischer (2004): conformance, performance, uncertainty, and dissemination, it was possible to differentiate the different proposed follow-up patterns in the environmental reports analysed. As seen in the previous section, when the ERs proposed a framework for follow-up, indicators were used as the assessment technique. However, this is mainly associated with the "performance" type of follow-up, which was also the most frequently proposed (used in 34 of 43 ERs). With the exception of ER SM13 which identified "indicators" for "uncertainty" follow-up, the other types of follow-up were described or had recommendations associated with them. Some ERs proposed more than one type of follow-up: in the Portuguese case, six ERs (A7, PM1, PM5, PM11, PM12, PM13), besides using performance follow-up also used conformance follow-up; and $A 1$ and $A 6$ proposed a framework that included all 
Paper published as follows: Polido, A., João, E. and Ramos, T. (2016), Strategic Environmental Assessment practices in European small islands: Insights from Azores and Orkney islands. Environmental Impact Assessment Review ,Volume 57, February 2016, Pages 18-30.

types of follow-up. As for the Scottish reports, SM10 and SM12 used performance and uncertainty follow-up, SM11 used performance and dissemination follow-up, and SM17 used performance, uncertainty and dissemination. Overall, there were four Azorean ERs (A2, A3, A4, and A5) and two SCT mainland (SM5 and SM8) that did not present a follow-up framework, and the Orkney ERs only presented a performance follow-up framework.

The attribution of responsibilities in the follow-up framework varies highly from the Portuguese ERs to the Scottish ERs. In the PT mainland cases, 12 out of 14 PT ERs (the exceptions are PM2 and PM14), present a list of entities responsible for follow-up beyond the "responsible authority". This list is associated with the "governance framework" referred to in the Portuguese guidelines (see Section 2), which intertwines also with stakeholder engagement in the SEA process. The "governance framework" usually has other authorities and stakeholders, including the public. From these 12 ERs PT mainland, 8 used the "governance framework" for the attribution of follow-up responsibilities. In the Azorean ERs, only two ERs make reference to the need to go beyond what is mandatory (A1 and A7), but in these cases, none of the reports show a specific list of entities with monitoring responsibilities.

In the Scottish mainland cases, only 4 out of 17 presented the entities beyond the "responsible authority" and their duties (SM2, SM6, SM9, and SM12), while in the Orkney ERs, 3 ERs denote specifically which entity and their duties, beyond the "responsible authority" (01, 02 and 03$)$. These third parties are organisations which are generally in charge of a specific indicator.

It was possible to identify a draft framework for future follow-up in 10 out of 14 PT mainland ERs, 3 out of 7 Azorean ERs, 10 out of 17 SCT mainland ERs, and 4 out of 5 Orkney ERs.

\subsection{Stakeholder engagement}

Overall, 13 Portuguese ERs presented a "governance framework" or the list of entities with environmental responsibilities, 12 PT mainland ERs (exceptions are PM2 and PM5) and one from Azores (A6). Nonetheless, ERs A1, A7 and PM5 made available the comments received during the ERs phase, which partially indicates which stakeholders were contacted. In the Scottish case, the ERs generally state that the "Consultation Authorities" will be consulted as well as the public. In the specific case of SM2, the plan steering group and the partnership responsible for the plan as additional stakeholders are identified, and were involved in different phases of the process.

As seen in Section 2, the Portuguese regulations give an illustrative list of entities to be consulted on the ER and therefore the number of entities with environmental responsibilities varies widely. This is in contrast to the three "Consultation Authorities" specified in SEA Scotland Act (2005). However, it is also noted that the participation of organizations, other than those with environmental responsibilities, is higher in the Portuguese case than in the Scottish one. Table 4 presents the number by type of stakeholders which responded to the ER consultation. Only one Scottish ER is included in the table because it was the only report with comments beyond the "Consultation Authorities".

Table 4 - Number by type of stakeholders which responded to consultation on the SEA environmental report

\begin{tabular}{|l|l|l|l|l|}
\hline Entities with & Public or Private & ONG and other & Individuals & Total responses \\
\hline
\end{tabular}




\begin{tabular}{|c|c|c|c|c|c|}
\hline & $\begin{array}{l}\text { environmental } \\
\text { responsibilities }\end{array}$ & organizations & civic organizations & & \\
\hline A1 & 14 & 2 & 1 & & 17 \\
\hline A6 & 3 & & & & 3 \\
\hline A7 & 2 & 1 & & & 3 \\
\hline PM5 & 29 & 2 & 18 & 4 & 53 \\
\hline PM6 & 13 & 2 & 1 & & 16 \\
\hline PM7 & 12 & 7 & & & 19 \\
\hline PM8 & 15 & 6 & 1 & & 22 \\
\hline PM9 & 15 & 2 & 1 & & 18 \\
\hline PM10 & 33 & 1 & 1 & & 35 \\
\hline PM11 & 9 & 2 & & & 11 \\
\hline PM12 & 23 & 3 & & & 26 \\
\hline PM13 & 12 & 3 & & & 15 \\
\hline PM14 & 23 & 1 & & & 24 \\
\hline SM13 & 3 & 2 & & & 5 \\
\hline
\end{tabular}

Note: the Table only shows the 13 PT ERs which provided the list of entities which responded to the consultation. Furthermore, only one Scottish report was considered because it was the only report with comments beyond the three statutory "Consultation Authorities".

The most used technique to engage with stakeholders is consultation, where the public is informed and invited to comment on the ER. However, some ERs mention different types of techniques used or foreseen. In three PT mainland ERs addressing the Water Framework Directive (PM11, PM12 and PM13) the teams used different types of public engagement for the plan (sectorial workshops and regional forums). Additionally, in $\mathrm{A} 1$ it is stated that three public meetings took place to discuss the plan and the SEA, while $A 2, A 3, A 4$ and $A 5$ state that it was expected to undertake public forums. In the Scottish case, beside the "Consultation Authorities", only two SCT mainland ERs made reference to steering group and partnership meetings, forums and workshops (SM2 and SM5). McLauchlan and João (2012) previously identified the poor participatory process in the Scottish case. Overall, there is little evidence on what was done specifically for the SEA consultation in both systems.

It needs to be highlighted that the information analysed for this paper encompasses only information within the ERs. However, the stakeholder engagement process may not be fully reflected in the ERs, and additional documents and investigation could be needed to understand the full stakeholder engagement process.

\section{Cross-case integrated analysis and discussion}

The Portuguese system, including the Azores, is more diverse in the types of guidelines used, contrasting with the Scottish SEA system, which has a strong predominance of the national guidance, and a regulation-based approach. The choice of using a certain type of guideline will necessarily influence the choice of the assessment topics, assessment techniques and methodological approaches. Similarly to what Noble et al. (2012) identified, the type of guidance, assessment topics, assessment techniques and methodological approaches used seems to be unrelated to the type of Plan, Programme or Strategy assessed, or the type of territory addressed, and is more dependent on the team that prepared the ER.

Additionally, McLauchlan and João (2012) found that ERs done by the same practitioners' teams are more prone to be uniform, which is also noted in the ERs studied in this research where the approaches used, the issues studied and even the indicators used in the assessment were 
Paper published as follows: Polido, A., João, E. and Ramos, T. (2016), Strategic Environmental Assessment practices in European small islands: Insights from Azores and Orkney islands. Environmental Impact Assessment Review ,Volume 57, February 2016, Pages 18-30.

systematically identical. This may reflect the practitioners' inability to do critical thinking which should be present in SEA, as demonstrated by McLauchlan and João (2012). It could also be due to the practitioners' lack of sufficient skills to develop such kinds of assessment, or of the time and resource constraints under which SEA system operates, as noted by João and McLauchlan (2014). This shows that the approaches used are based on the knowledge of the practitioner and not on the different SEA contexts (Noble et al., 2012). This may be even more noticeable in territories such as small islands, due to their relatively small populations, which may reveal a dearth of specific SEA expertise and experience, as discussed by Mclntyre (2005) and Crossley and Sprague (2014). These findings are in line with what has been recently debated about the enhancement of the wider concept of sustainability in small islands (e.g., Crossley and Sprague, 2014). There is still need for further development of specific SEA capacity-building initiatives in these territories, even though there are already some positive signals, such as the SEAs done by the University of Azores' team, showing progress towards such capacity enhancement.

The use of the different guidelines would suggest different types of assessment topics selected and used in the ERs. Indeed, the Portuguese ERs presented types of assessment topics distinct from those used for the Scottish ERs, indicating topics built from a mixed approach, including, in some cases, stakeholder inputs as opposed to Directive-based assessment topics per se. As suggested by Ramos et al. (2009) topics chosen for the assessment should reflect small islands, and this was often found in the study. The subjects of the topics used in the small islands case studies are in line with the priority areas and inherent concerns for small islands, as highlighted by the international community for small islands (see United Nations, 2005, 1994), even though there are some priority areas missing from the ERs (e.g. regional institutions and technical cooperation, transport and communication, science and technology).

Also, the additional findings of Noble et al. (2012) have an echo in the Portuguese and Scottish reports analysed from mainland and islands, where there is a predominance of qualitative methods, such as expert judgement, and SWOT analysis, even the impact matrices were mainly done qualitatively. However, while the Portuguese system presents the use of multiple methods among the different sections of the ERs, being the "Assessment of effects" section that uses the greater range of methods, the Scottish system uses a lesser range of methods, usually using just one method per assessment phase. From the analysis made to the methods used, the lack of context specificity of the approaches in these small islands was verified. Furthermore, these findings also underscore what was previously recommended by Ramos et al. (2009); assessment techniques and methods must weight variables according to the small islands' particular criteria and thresholds. However, it needs to be noted that recent legislation and guidelines give signs that future assessment may include a greater diversity in the approaches used, such as climate proofing (see Azorean Regional Decree-Law 30/2010/A) and ecosystems (see Scottish Government 2013). This is in line with recent trends for SEA approaches concerning resilience (e.g., Slootweg and Jones, 2011), and ecosystem services (e.g., Baker et al., 2013).

It is necessary to point out that although "indicators" might not have been explicitly stated in most SEA phases (except in "establishing the context"), indicators were used within the technique "sustainability framework and indicators", and in "follow-up". Indicators were also used across the full assessment to support the different techniques used, such as, "impact matrices" and "trend 
Paper published as follows: Polido, A., João, E. and Ramos, T. (2016), Strategic Environmental Assessment practices in European small islands: Insights from Azores and Orkney islands. Environmental Impact Assessment Review ,Volume 57, February 2016, Pages 18-30.

analysis". Indicators by themselves are an assessment technique (Fischer, 2007), as they may operationalise themes and objectives set out for the SEA (Therivel 2004). Also, the findings are consistent with what was confirmed by Therivel (2004) and Fischer (2007): indicators can be used in all assessment situations and SEA stages, to describe and monitor the baseline information or to predict impacts. In the ERs analysed, the information was not always clear and systematized, rendering it difficult to understand the concepts and approaches associated with the use of those indicators. In the majority of the reports, the indicators used to characterise the baseline situation constitute the core indicators proposed for the follow-up. Due to their cross-cutting characteristics and influence in all SEA stages, Donnelly et al. (2006) recommends their consideration, starting from the early stages, in order to achieve an effective SEA.

Concerning the follow-up stage, the results show that the majority of the reports presented a followup framework, where the most common technique in the performance follow-up framework was "indicators" (see Section 4.3). However, these frameworks do not differ much between the small islands and the mainland reports. As recommended by Nilsson et al. (2009), follow-up strategies should be developed according with the PPS context, taking into account appropriate indicators and other techniques. It can thus be suggested that specific follow-up strategies are needed for small islands. Furthermore, and as demonstrated by Nilsson et al. (2009), it is important to have a systematic framework in order to separate direct environmental effects from indirect long-term effects, and to understand what the cumulative effects are.

Additionally, Nilsson et al. (2009) showed the importance of the inclusion of participatory approaches to access specific knowledge and experiences concerning impacts in the follow-up stage. In this research, only the Portuguese mainland ERs presented a "governance framework" which listed different stakeholders and their responsibilities within the follow-up framework. These findings highlight the need to enhance SEA follow-up frameworks to go beyond what is currently done, to include further stakeholder engagement in this stage, and the need to take into account the different contexts of the SEA, as recommended by different authors (e.g., Morrison-Saunders et al., 2014; Nilsson et al., 2009).

Stakeholder engagement is an SEA cross-cutting issue, and for Noble (2004), assessments should effectively include stakeholders knowledge and values. Additionally, Fischer (2007) states stakeholders may identify different interests in the PPS-making process. These arguments support what was done in four Azorean reports made with an "SEA team own approach", which used expert judgement and defined a clear strategy for stakeholder engagement. As noted by Polido et al. (2014), community awareness and empowerment need to be effective in small islands. Therefore, there is some evidence that to ensure an effective SEA in these territories, different stakeholders, including the public, should be engaged since SEA early stages. This indicates that stakeholder engagement could be used as an assessment technique, even if combined with other techniques, throughout the full assessment and not only in specific SEA stages, such as after the issuing of a draft SEA report. Furthermore, evidence from this research point to an easier integration of participatory approaches in Azores, which has already inputs from different stakeholders, but less in Orkney where the main external inputs are from the "Consultation Authorities". Nonetheless, in both cases there should be government-level provisions for the development of these types of approaches, as argued by Bass and Dalal-Clayton (1995) and Zubair et al. (2011) . 
Paper published as follows: Polido, A., João, E. and Ramos, T. (2016), Strategic Environmental Assessment practices in European small islands: Insights from Azores and Orkney islands. Environmental Impact Assessment Review ,Volume 57, February 2016, Pages 18-30.

\section{Conclusion}

This research set out to profile SEA in European small islands, using as a case study the Azores and Orkney islands, and at the same time to provide insights on what could be improved in SEA of these territories. Despite its exploratory nature and limited sample of Azorean and Orkney ERs, this study offers a background for future research on SEA in context-specific applications.

Overall, the research found no distinct features from SEA of the small islands studied when compared with the corresponding mainland, despite the vast literature referring to the importance of SEA context-specific approaches, including territories with specific features. The guidelines used, the assessment topics, the assessment techniques, and the overall structure of the ER, depends mainly on the team that develops the SEA, instead of the context of the PPS. These findings suggest there is a need for the enhancement of practitioners' SEA knowledge and capacity, to explore the development of tailored approaches. Enhancing decision-maker, practitioner, and stakeholder capacity, including the public, in context-specific applications in these territories, is a key-issue to take into account when developing SEA sustainability-led approaches.

This study also found that the use of participatory approaches throughout the assessment, in the different SEA stages and as an assessment technique, should be better characterised and supported in the ER, playing a central role when developing approaches for these territories. This should be implemented from the SEA scoping phase, and used in combination with other assessment tools and techniques. This could entail a deep commitment from national and regional/local governments, through the development and implementation of a tool or process which supports a participative assessment, with different stakeholders, including the public.

Strengthening networks between small islands for the exchange of knowledge and experiences, and cooperation with international agencies could help effectively integrate specific features in these territories. If the debate about small island-specific approaches is to be moved forward, the paradigm must change and collaborative approaches for the development of SEA need to be enhanced.

\section{Acknowledgements}

The authors would like to thank the several SEA practitioners in Scotland and Portugal who were consulted during the research and to André Mascarenhas, Lia Vasconcelos, Martina Hölzl, and Rodrigo Lozano, for taking their time to read and comment on previous versions of this paper. Also, Paula Antunes and Rui Santos for their helpful insights during the "PhD in Environmental and Sustainability Studies - Spring Seminar 2015". The authors thank the two anonymous reviewers for their thorough revision which helped improve the paper. Additionally, the first author would like to thank to Ana Rita Domingues, Inês Cosme and Patrícia Ferreira, for their continuous support and comments. The authors acknowledge the financial support of Fundação para a Ciência e Tecnologia through the scholarship SFRH/BD/77091/2011 given to the first author. CENSE is financed through Strategic Project Pest-OE/AMB/UI4085/2013 from Fundação para a Ciência e Tecnologia, Portugal.

\section{References}

Abaza, H., Bisset, R., Sadler, B., 2004. Environmental Impact Assessment and Strategic Environmental 
Paper published as follows: Polido, A., João, E. and Ramos, T. (2016), Strategic Environmental Assessment practices in European small islands: Insights from Azores and Orkney islands. Environmental Impact Assessment Review ,Volume 57, February 2016, Pages 18-30.

Assessment: Towards an Integrated Approach. UNEP, Geneva.

Adrianto, L., Matsuda, Y., 2002. Developing economic vulnerability indices of environmental disasters in small island regions. Environ. Impact Assess. Rev. 22, 393-414. doi:10.1016/S01959255(02)00012-4

Andrade, C., Borges, P., Freitas, M.C., 2006. Historical tsunami in the Azores archipelago (Portugal). J. Volcanol. Geotherm. Res. 156, 172-185. doi:10.1016/j.jvolgeores.2006.03.014

Baker, J., Sheate, W.R., Phillips, P., Eales, R., 2013. Ecosystem services in environmental assessment - Help or hindrance? Environ. Impact Assess. Rev. 40, 3-13. doi:10.1016/j.eiar.2012.11.004

Bardin, L., 1977. Content Analysis [Portuguese Ed. - Trans. Luís Antero Reto and Augusto Pinheiro]. Edições 70, Lisbon.

Bass, S., Dalal-Clayton, B., 1995. Small island states and sustainable development: strategic issues and experience, Environment Planning Issues. International Institute for Environment and Development, London.

Bond, A., Morrison-Saunders, A., Gunn, J.A.E., Pope, J., Retief, F., 2015. Managing uncertainty, ambiguity and ignorance in impact assessment by embedding evolutionary resilience, participatory modelling and adaptive management. J. Environ. Manage. 151, 97-104. doi:10.1016/j.jenvman.2014.12.030

Borges, M. de F., Cabral, H., Andrade, F., 2009. Ocean [in Portuguese], in: Pereira, H.M., Domingos, T., Vicente, L., Proença, V. (Eds.), Ecosystems and Human Well-Being: Portuguese Assessment of the Millennium Ecosystem Assessment [in Portuguese]. Escolar Editora, Lisbon, pp. 437-461.

Borges, P., Andrade, C., Freitas, M.C., 2002. Dune, Bluff and Beach Erosion due to Exhaustive Sand Mining - the Case of Santa Barbara Beach , São Miguel (Azores , Portugal). J. Coast. Res. ICS 2002 P, 89-95.

Bryman, A., 2012. Social Research Methods, 2nd ed. Oxford University Press, New York.

Calado, H., Borges, P., Phillips, M., Ng, K., Alves, F., 2011a. The Azores archipelago, Portugal : improved understanding of small island coastal hazards and mitigation measures. Nat. Hazards 58, 427-444. doi:10.1007/s11069-010-9676-5

Calado, H., Ng, K., Borges, P., Alves, F., Sousa, L., 2011b. Climate Change and Coastal Tourism in the Azores Archipelago, in: Jones, A., Phillips, M. (Eds.), Disappearing Destinations: Climate Change and Future Challenges for Coastal Tourism. CAB International, Chippenham.

Carvalho, N., Rege, S., Fortuna, M., Isidro, E., Edwards-jones, G., 2011. Estimating the impacts of eliminating fi sheries subsidies on the small island economy of the Azores. Ecol. Econ. 70, 18221830. doi:10.1016/j.ecolecon.2011.05.013

Chaker, A., El-Fadl, K., Chamas, L., Hatjian, B., 2006. A review of strategic environmental assessment in 12 selected countries. Environ. Impact Assess. Rev. 26, 15-56.

doi:10.1016/j.eiar.2004.09.010 
Paper published as follows: Polido, A., João, E. and Ramos, T. (2016), Strategic Environmental Assessment practices in European small islands: Insights from Azores and Orkney islands. Environmental Impact Assessment Review ,Volume 57, February 2016, Pages 18-30.

Crossley, M., Sprague, T., 2014. Education for sustainable development: Implications for small island developing states (SIDS). Int. J. Educ. Dev. 35, 86-95. doi:10.1016/j.ijedudev.2013.03.002

Deschenes, P.J., Chertow, M., 2004. An island approach to industrial ecology: towards sustainability in the island context. J. Environ. Plan. Manag. 47, 201-217. doi:10.1080/0964056042000209102

DGOTDU (Direcç̧ão-Geral do Ordenamento do Território e Desenvolvimento Urbano), 2008. Environmental Assessment Guidance for Local Spatial Plans [in Portuguese]. DGOTDU, Lisbon.

DGT (Direção-Geral do Território), 2014. Civil parishes, municipalities and district areas of CAOP 2014 [in Portuguese] [WWW Document]. CAOP (Carta Adm. Of. Port. URL http://www.dgterritorio.pt/cartografia_e_geodesia/cartografia/carta_administrativa_oficial_d e_portugal_caop_/caop_em_vigor/(accessed 6.1.15).

Donnelly, A., Jones, M., O’Mahony, T., Byrne, G., 2006. Decision-support framework for establishing objectives, targets and indicators for use in strategic environmental assessment. Impact Assess. Proj. Apprais. 24, 151-157. doi:10.3152/147154606781765246

Doren, D. van, Driessen, P.P.J., Schijf, B., Runhaar, H.A.C., 2013. Evaluating the substantive effectiveness of SEA: Towards a better understanding. Environ. Impact Assess. Rev. 38, 120 130. doi:10.1016/j.eiar.2012.07.002

Douglas, C.H., 2006. Small Island States and Territories : Sustainable Development Issues and Strategies - Challenges for Changing Islands in a Changing World. Sustain. Dev. 14, 75-80.

DRA (Direção Regional do Ambiente), GP-SRAA (Gabinete de Planeamento da Secretaria Regional da Agricultura e Ambiente), DRAM (Direção Regional dos Assuntos do Mar), 2014. Report on the State of the Environment of the Azores 2011-2013 [in Portuguese]. Açores.

Eurostat, 2014. Administrative units / Statistical units [WWW Document]. URL http://ec.europa.eu/eurostat/web/gisco/geodata/reference-data/administrative-unitsstatistical-units (accessed 6.1.15).

Fischer, T.B., 2007. Theory \& Practice of Strategic Environmental Assessment: Towards a more systematic approach. Earthscan, London.

Fischer, T.B., 2002. Strategic environmental assessment in transport and land use planning. Earthscan Publications, London.

Fischer, T.B., Gazzola, P., 2006. SEA effectiveness criteria-equally valid in all countries? The case of Italy. Environ. Impact Assess. Rev. 26, 396-409. doi:10.1016/j.eiar.2005.11.006

Fischer, T.B., Onyango, V., 2012. Strategic environmental assessment-related research projects and journal articles: an overview of the past 20 years. Impact Assess. Proj. Apprais. 30, 253-263. doi:10.1080/14615517.2012.740953

Gauthier, M., Simard, L., Waaub, J.-P., 2011. Public participation in strategic environmental assessment (SEA): Critical review and the Quebec (Canada) approach. Environ. Impact Assess. 
Paper published as follows: Polido, A., João, E. and Ramos, T. (2016), Strategic Environmental Assessment practices in European small islands: Insights from Azores and Orkney islands. Environmental Impact Assessment Review, Volume 57, February 2016, Pages 18-30.

Rev. 31, 48-60. doi:10.1016/j.eiar.2010.01.006

Gunn, J.H., Noble, B.F., 2009. A conceptual basis and methodological framework for regional strategic environmental assessment (R-SEA). Impact Assess. Proj. Apprais. 27, 258-270. doi:10.3152/146155109X479440

Hartley, J., 2004. Case Study Research, in: Cassell, C., Symon, G. (Eds.), Essential Guide to Qualitative Methods in Organizational Research. SAGE Publications, Ltd., London, pp. 323-333.

Highlands and Islands Enterprise, 2014. Orkney Area Profile. Inverness.

Hildén, M., Furman, E., Kaljonen, M., 2004. Views on planning and expectations of SEA: the case of transport planning. Environ. Impact Assess. Rev. 24, 519-536. doi:10.1016/j.eiar.2004.01.003

IAIA (International Association for Impact Assessment), 2002. Strategic environmental assessment Performance Criteria.

Jackson, T., Dixon, J., 2006. Applying strategic environmental assessment to land-use and resourcemanagement plans in Scotland and New Zealand: a comparison. Impact Assess. Proj. Apprais. 24, 89-101. doi:10.3152/147154606781765255

Jackson, T., Illsley, B., 2007. An analysis of the theoretical rationale for using strategic environmental assessment to deliver environmental justice in the light of the Scottish Environmental Assessment Act. Environ. Impact Assess. Rev. 27, 607-623. doi:http://dx.doi.org/10.1016/j.eiar.2007.05.004

João, E., McLauchlan, A., 2014. Would you do SEA if you didn't have to?- Reflections on acceptance or rejection of the SEA process. Impact Assess. Proj. Apprais. 32, 87-97. doi:10.1080/14615517.2014.889265

Kelly, A.H., Jackson, T., Williams, P., 2012. Strategic environmental assessment: lessons for New South Wales, Australia, from Scottish practice. Impact Assess. Proj. Apprais. 30, 75-84. doi:10.1080/14615517.2012.660351

Kerr, S.A., 2005. What is small island sustainable development about? Ocean Coast. Manag. 48, 503524. doi:10.1016/j.ocecoaman.2005.03.010

Krippendorff, K., 2003. Content Analysis: An Introduction to Its Methodology, 2nd ed. Sage Publications, Inc, Thousand Oaks, California.

Mayring, P., 2000. Qualitative content analysis. Forum Qual. Soc. Res. 1, Art. 20.

McIntyre, M., 2005. Pacific Environment Outlook. UNEP and SPREP.

McKirdy, A., 2010. Orkney and Shetland: a landscape fashioned by geology. Scottish Natural Heritage, Perth.

McLauchlan, A., João, E., 2012. The inherent tensions arising from attempting to carry out strategic environmental assessments on all policies, plans and programmes. Environ. Impact Assess. Rev. 36, 23-33. doi:10.1016/j.eiar.2012.03.002 
Paper published as follows: Polido, A., João, E. and Ramos, T. (2016), Strategic Environmental Assessment practices in European small islands: Insights from Azores and Orkney islands. Environmental Impact Assessment Review ,Volume 57, February 2016, Pages 18-30.

Montaño, M., Oppermann, P., Malvestio, A.C., Souza, M.P., 2014. Current State of the Sea System in Brazil: a Comparative Study. J. Environ. Assess. Policy Manag. 16, 1450022. doi:10.1142/S1464333214500227

Morrison-Saunders, A., Pope, J., Bond, A., Retief, F., 2014. Towards sustainability assessment followup. Environ. Impact Assess. Rev. 45, 38-45. doi:10.1016/j.eiar.2013.12.001

Nagarajan, P., 2006. Collapse of Easter Island: Lessons for Sustainability of Small Islands. J. Dev. Soc. 22, 287-301. doi:10.1177/0169796X06068032

National Records of Scotland, 2013a. 2011 Census: First Results on Population and Household Estimates for Scotland - Release 1C (Part Two).

National Records of Scotland, 2013b. Scotland's Census 2011: Table KS101SC - Usual resident population.

National Records of Scotland, 2013c. Our Products>Other National Records of Scotland (NRS) Geographies Datasets>Islands Boundaries [WWW Document]. URL http://www.nrscotland.gov.uk/statistics-and-data/geography/our-products/other-nationalrecords-of-scotland-nrs-geographies-datasets (accessed 6.1.15).

Newitt, M., 1992. Introduction, in: Hintjens, H.M., Newitt, M.D.D. (Eds.), The Political Economy of Small Tropical Islands: The Importance of Being Small. University of Exeter Press, Exeter.

Nilsson, M., Wiklund, H., Finnveden, G., Jonsson, D.K., Lundberg, K., Tyskeng, S., Wallgren, O., 2009. Analytical framework and tool kit for SEA follow-up. Environ. Impact Assess. Rev. 29, 186-199. doi:10.1016/j.eiar.2008.09.002

Noble, B.F., 2004. Strategic environmental assessment quality assurance: evaluating and improving the consistency of judgments in assessment panels. Environ. Impact Assess. Rev. 24, 3-25. doi:10.1016/S0195-9255(03)00118-5

Noble, B.F., Gunn, J., Martin, J., 2012. Survey of current methods and guidance for strategic environmental assessment. Impact Assess. Proj. Apprais. 30, 139-147. doi:10.1080/14615517.2012.705076

ODPM (Office of the Deputy Prime Minister), 2005. A Practical Guide to the Strategic Environmental Assessment Directive. Office of the Deputy Prime Minister, London.

OECD (Organisation for Economic Co-Operation and Development), 2006. Applying Strategic Environmental Assessment: Good practice guidance for development co-operation. OECD Publications, Paris.

Orkney Islands Council, 2012. Strategic Environmental Assessment of the Orkney Local Development Plan: Appendix B - Environmental Baseline Report. Kirkwall.

Orkney Islands Council, 2007. Local Transport Strategy 2007-2010: A draft strategy for all of Orkney. Kirkwall.

Partidário, M.R., 2012. Strategic Environmental Assessment Better Practice Guide - methodological 
Paper published as follows: Polido, A., João, E. and Ramos, T. (2016), Strategic Environmental Assessment practices in European small islands: Insights from Azores and Orkney islands. Environmental Impact Assessment Review ,Volume 57, February 2016, Pages 18-30.

guidance for strategic thinking in SEA. Agência Portuguesa do Ambiente e Redes Energéticas Nacionais, Lisboa.

Partidário, M.R., 2007. Strategic Environmental Assessment Good Practices Guide - Methodological Guidance. Portuguese Environmental Agency, Amadora.

Partidário, M.R., Fischer, T.B., 2004. Follow-up in current SEA understanding, in: Morrison-Saunders, A., Arts, J. (Eds.), Assessing Impact: Handbook of EIA and SEA Follow-Up. Earthscan, London, pp. 224-247.

Partidário, M.R., Nunes, D., Lima, J., 2010. Criteria definition and evaluation of Environmental Reports [in Portuguese]. Agência Portuguesa do Ambiente, Amadora.

Polido, A., João, E., Ramos, T.B., 2014. Sustainability approaches and strategic environmental assessment in small islands : An integrative review. Ocean Coast. Manag. 96, 138-148.

Polido, A., Ramos, T.B., 2015. Towards effective scoping in strategic environmental assessment. Impact Assess. Proj. Apprais. 33, 171-183. doi:10.1080/14615517.2014.993155

Rachid, G., El Fadel, M., 2013. Comparative SWOT analysis of strategic environmental assessment systems in the Middle East and North Africa region. J. Environ. Manage. 125, 85-93. doi:10.1016/j.jenvman.2013.03.053

Ramjeawon, T., Beedassy, R., 2004. Evaluation of the EIA system on the Island of Mauritius and development of an environmental monitoring plan framework. Environ. Impact Assess. Rev. 24, 537-549. doi:10.1016/j.eiar.2004.01.001

Ramos, T.B., Caeiro, S., Douglas, C.H., Ochieng, C., 2009. Environmental and sustainability impact assessment in small islands: the case of Azores and Madeira. Int. J. Environ. Technol. Manag. 10, 223-240. doi:10.1504/IJETM.2009.023523

Ren, L., Shang, J., 2005. Necessity and method of public participation in strategic environmental assessment of China. Chinese Geogr. Sci. 15, 42-46. doi:10.1007/s11769-003-0067-7

Saunders, M., Lewis, P., Thornhill, A., 2009. Research Methods for Business Students, 5th ed. Prentice Hall, Harlow.

Scottish Executive, 2006. Strategic Environmental Assessment Tool Kit. Scottish Executive, Edinburgh.

Scottish Government, 2013. Strategic Environmental Assessment Guidance. Scottish Government with the support and input from the Scottish SEA Forum members, including Scotland's SEA Consultation Authorities - Scottish Natural Heritage, Scottish Environment Protection Agency and Historic Scotland, Edinburgh.

Scottish Government, n.d. Strategic Environmental Assessment (SEA) Database [WWW Document]. URL http://www.gov.scot/Topics/Environment/environmental-assessment/sea/SEAG (accessed 4.9.15).

Scottish Government/Environmental Assessment Team, SNH (Scottish Natural Heritage), SEPA 
Paper published as follows: Polido, A., João, E. and Ramos, T. (2016), Strategic Environmental Assessment practices in European small islands: Insights from Azores and Orkney islands. Environmental Impact Assessment Review, Volume 57, February 2016, Pages 18-30.

(Scottish Environmental Protection Agency), Historic Scotland, 2015. Environmental Assessment: Newsletter (July).

SEEG (Scottish Executive Environment Group), 2004. Strategic Environmental Assessment (Scotland) Bill - a Consultation, Paper 2004/12. Scottish Executive.

SEPA (Scottish Environmental Protection Agency), 2011. The Scottish Strategic Environmental Assessment Review. SEPA. Prepared in association with Historic Scotland and Scottish Natural Heritage, Stirling, Scotland.

Slootweg, R., Jones, M., 2011. Resilience thinking improves SEA : a discussion paper. Impact Assess. Proj. Apprais. 29, 263-276. doi:10.3152/146155111X12959673795886

SPCB (Scottish Parliament Corporate Body), 2005. Environmental Assessment (Scotland) Bill Explanatory Notes (and another accompanying documents). Scottish Parliament.

SRAF (Secretaria Regional da Agricultura e Florestas), 2011. Rural Development Programme of the Autonomous Region of the Azores - PRORURAL 2007-2013 [in Portuguese], 5th ed. Secretaria Regional da Agricultura e Florestas, Azores.

SREA (Serviço Regional de Estatística dos Açores), 2012. Census 1991, 2001 and 2011: Definite main results [in Portuguese]. Angra do Heroísmo.

Suárez de Vivero, J.L., 1995. Atlantic archipelagic regions: self-government and ocean management in the Azores, Madeira and Canary Islands. Ocean Coast. Manag. 27, 47-71. doi:10.1016/09645691(95)00028-3

Therivel, R., 2004. Strategic Environmental Assessment in Action. Earthscan, London and Sterling, VA. doi:10.1017/S1466046606230151

Therivel, R., 1993. Systems of strategic environmental assessment. Environ. Impact Assess. Rev. 13, 145-168. doi:10.1016/0195-9255(93)90029-B

Transport Scotland, 2013. STAG Technical Database. The Scottish Government, Edinburgh.

Transport Scotland, 2008. Scottish Transport Appraisal Guidance. The Scottish Government, Edinburgh.

UNCED (United Nations Conference on Environment and Development), 1992. Agenda 21: Programme of Action for Sustainable Development. Rio de Janeiro.

UNEP (United Nations Environment Programme), 2009. Integrated Assessment: Mainstreaming into Policymaking (A Guidance Manual). UNEP, Geneve.

United Nations, 2005. Report of the International Meeting to Review the Implementation of the Programme of Action for the Sustainable Development of Small Island Developing States (A/CONF.207/11). Port Louis, Mauritius.

United Nations, 1994. Report of the Global Conference on the Sustainable Development of Small Island Developing States (A/CONF.167/9). Bridgetown, Barbados. doi:10.1016/0964- 
Paper published as follows: Polido, A., João, E. and Ramos, T. (2016), Strategic Environmental Assessment practices in European small islands: Insights from Azores and Orkney islands. Environmental Impact Assessment Review ,Volume 57, February 2016, Pages 18-30.

\section{$5691(94) 90039-6$}

Yin, R.K., 2009. Case Study Research: Design and Methods, 4th ed. SAGE Publications, Inc., Thousand Oaks, California.

Zhou, K., Sheate, W.R., 2009. Comparative analysis of SEA legal requirements and institutional structure in China (Mainland), Canada and the UK (England). J. Environ. Assess. Policy Manag. $11,387-426$

Zubair, S., Bowen, D., Elwin, J., 2011. Not quite paradise: Inadequacies of environmental impact assessment in the Maldives. Tour. Manag. 32, 225-234. doi:10.1016/j.tourman.2009.12.007 